\title{
Cotransfer of regulatory $T$ cells improve the therapeutic effectiveness of mesenchymal stem cells in treating a colitis mouse model
}

\author{
Yang $\mathrm{YU}^{1-3)}$, Tianyu $\mathrm{ZHAO}^{1-3)}$, and Deqin $\mathrm{YANG}^{1-3)}$ \\ ${ }^{1)}$ Stomatological Hospital of Chongqing Medical University, Chongqing, P. R. China \\ ${ }^{2)}$ Chongqing Key Laboratory of Oral Diseases and Biomedical Sciences, Chongqing, P. R. China \\ ${ }^{3)}$ Chongqing Municipal Key Laboratory of Oral Biomedical Engineering of Higher Education, Chongqing, P. R. China
}

\begin{abstract}
Inflammatory bowel disease (IBD) is a severe inflammatory condition in the colon. To date, clinical solutions for this disease have been limited. Mesenchymal stem cells (MSCs), multipotential cells with immune regulation and anti-inflammatory functions, have been applied to treatment of IBD. However, the therapeutic effectiveness of MSCs still needs to be improved. Here, we were interested in whether regulatory $T$ cells (Tregs) could enhance the immune regulation function of MSCs in treatment of mouse colitis. We generated a dextran sulfate sodium (DSS)-induced IBD mouse model. Combined cell therapy with both MSCs and Tregs was able to help increase body weight and preserve a better colon morphology compared with single cell therapy with MSCs or Tregs alone. Further studies demonstrated that combined cell therapy could reduce pro-inflammatory cytokines such as TNF- $\alpha, I L-10$, IFN- $\gamma$, IL-17A, IL-1 $\beta$ and at the same time promote $C D 3^{+} T$ cells apoptosis. In conclusion, our study indicates that combined cell therapy could prevent the development of colitis in a mouse model, which may lead to a new effective therapeutic approach for treatment of human IBD.
\end{abstract}

Key words: colitis, mesenchymal stem cells, regulatory T cells

\section{Introduction}

Inflammatory bowel disease (IBD) is a chronic disorder with uncontrolled inflammation that will ultimately lead to severe dysfunction of the gastrointestinal tract [4]. Nowadays, anti-inflammatory reagents and immune regulation reagents, such as glucocorticoids, are widely used to treat IBD. However, they are not fully effective [2]. In addition, these immune regulation reagents normally have multiple cellular targets, which may lead to severe side effects [10]. How to treat IBD with both specificity and effectiveness still remains to be determined.

Mesenchymal stem cells (MSCs) have been widely used for tissue repair. Intriguingly, MSCs could also serve as an effective immunosuppressive agent. Plenty of studies have shown that MSCs have been involved in regulating multiple immune responses, such as inhibiting $\mathrm{T}$ cells proliferation, suppressing dendritic cell (DC) maturation, and increasing $\mathrm{T}$ cells apoptosis $[1,5,6,11$, $14,20]$. Based on these immune regulation activities, MSCs have been applied in treating many immune diseases, for example, graft-versus-host disease (GVHD), rheumatoid arthritis (RA), and systemic lupus erythematosus (SLE) [3, 16, 26, 27]. It is also known that the therapeutic function of MSCs could be amended by many cellular-environmental conditions including inflammation. Several studies have demonstrated that pretreatment with pro-inflammatory cytokines, such as interferon- $\gamma$ (IFN- $\gamma$ ), interleukin-1 $\beta$ (IL-1 $\beta$ ), interleukin-10 (IL-10), and tumor necrosis factor (TNF- $\alpha$ ), could enhance the therapeutic effects of MSCs in mice with colitis $[8,9]$. 
Additionally, $\mathrm{CD} 4^{+} \mathrm{CD} 25^{+} \mathrm{Foxp}^{+} \mathrm{T}$ regulatory cells (Tregs) could be induced by MSCs, and the immune regulation activities of MSCs might, at least partially, benefit from Tregs' presence. There is evidence showing that Tregs could boost the MSCs' immunomodulatory effects when treating GVDH [17]. In this study, we investigated the outcome of combined cell therapy with both MSCs and Tregs in treatment of treating DSS-induced colitis in a mouse model. We found that the combined cell therapy could increase body weight and preserve a better colon morphology compared with treatment with either MSCs or Tregs alone. Further studies showed that combined cell therapy achieved much better results in promoting $\mathrm{CD}^{+} \mathrm{T}$ cell apoptosis and reducing proinflammatory cytokines. Our study indicated that combining Tregs and MSCs in cell-based therapy could prevent the development of colitis in a mouse model, which may lead to a potential strategy for treatment of human IBD.

\section{Materials and Methods}

Mice

Eight-week-old C57BL/6 mice were purchase from the animal center of Chongqing Medical University in Chongqing, China. All animal experiments were performed under the experimental animal guidelines of the National Institutes of Health and approved by the Animal Care and Use Committee of Chongqing Medical University.

\section{Isolation and characterization of MSCs}

Mouse bone marrow cells were flushed out from femurs and tibias with $\alpha$-MEM medium (Invitrogen, Carlsbad, CA, USA) containing $10 \mathrm{U} / \mathrm{ml}$ penicillin (Invitrogen, Carlsbad, CA, USA), $10 \mathrm{~g} / \mathrm{ml}$ streptomycin (Invitrogen, Carlsbad, CA, USA), 2 mM L-glutamine (HyClone, GE Healthcare Life Sciences, Logan, UT, USA), and 20\% fetal bovine serum (FBS) (HyClone, GE Healthcare Life Sciences, Logan, UT, USA). To characterize the MSCs, cultured bone marrow cells were analyzed by flow cytometry. Briefly, cells were washed twice with flow cytometry buffer and diluted at $1 \times 10^{6}$ cells/ $\mathrm{ml}$ before incubation with conjugated monoclonal antibodies against Sca-1-PE (Abcam, Cambridge, UK), CD73-PE (eBioscience, San Diego, CA, USA), CD 90PE (BioLegend, San Diego, CA, USA), CD105-PE (BioLegend, San Diego, CA, USA), CD14-PE (Abcam,
Cambridge, UK), CD34-PE (BioLegend, San Diego, CA, USA), CD11b-PE (BioLegend, San Diego, CA, USA), and CD45-PE (eBioscience, San Diego, CA, USA) according to the manufacturers' instructed. After washing with PBS, cells were subjected to flow cytometric analysis (Beckman Coulter, Fullerton, CA, USA).

\section{Osteogenic/adipogenic differentiation of MSCs}

The osteogenic/adipogenic differentiation experiments for MSCs were performed as previously described [8]. First, $1 \times 10^{5}$ cells/well were seeded onto 6-well plates and cultured in $\alpha$-MEM containing $20 \%$ FBS, $2 \mathrm{mM}$ L-glutamine, $10 \mathrm{U} / \mathrm{ml}$ penicillin, and $10 \mathrm{~g} / \mathrm{ml}$ streptomycin. Osteogenic differentiation medium was prepared with $100 \mathrm{~nm}$ dexamethasone (Sigma-Aldrich, St. Louis, MO, USA), $50 \mathrm{ug} / \mathrm{ml}$ ascorbic acid (Sigma-Aldrich, St. Louis, MO, USA) and $5 \mathrm{mM} \beta$-glycerophosphate (Sigma-Aldrich, St. Louis, MO, USA). Adipogenic differentiation medium was composed $0.5 \mathrm{mM}$ methylisobutylxanthine (Sigma-Aldrich, St. Louis, MO, USA), $0.5 \mathrm{mM}$ hydrocortisone (Sigma-Aldrich, St. Louis, MO, USA), and $60 \mathrm{mM}$ indomethacin (Sigma-Aldrich, St. Louis, MO, USA). The newly prepared MSCs were cultured in either osteogenic or adipogenic differentiation medium for a defined time period. For observation, the cells were fixed with $75 \%$ ethanol and then stained with Oil Red O solution or 2\% Alizarin Red (Sigma-Aldrich, St. Louis, MO, USA), respectively.

\section{Tregs generation}

Tregs were prepared according to the all-trans retinal method as described previously [17]. Briefly, spleens were harvested from $\mathrm{C} 57 \mathrm{BL} / 6$ mice. $\mathrm{CD} 4^{+} \mathrm{T}$ cells were isolated by using a Dynal ${ }^{\circledR}$ CD4 Negative Isolation Kit (Dynal Biotect, Bromborough, Wirral, UK). These cells were then cultured with anti-CD3 (BioLegend, San Diego, CA, USA), anti-CD28 (BioLegend, San Diego, CA, USA), TGF- $\beta$ (PeproTech, London, UK), and retinal acid (Sigma-Aldrich, St. Louis, MO, USA) for 72 h. CD4 ${ }^{+}$ $\mathrm{CD} 25^{+}$cells were sorted out of the culture by flow cytometry and analyzed with cell surface antibodies, such as anti-CD4 -FITC (Abcam, Cambridge, UK), antiCD25-PE (BD PharMingen, San Diego, CA, USA), anti-FOXP3-APC (BD PharMingen, San Diego, CA, USA), anti-CD44 (BioLegend, San Diego, CA, USA), anti-GITR (BioLegend, San Diego, CA, USA), and anti-CTL4 (BioLegend, San Diego, CA, USA). 


\section{Induction of colitis}

Mice were treated with $3 \%(\mathrm{w} / \mathrm{v})$ DSS water (MP Biomedicals, Solon, OH, USA) from day 0 to day 10 . On day 3 , experimental mice were injected intravenously with $1 \times 10^{6} \mathrm{MSCs}, 2 \times 10^{6}$ Tregs, or the combination of $1 \times 10^{6} \mathrm{MSCs}$ and $2 \times 10^{6}$ Tregs. Control animals were given an equal volume of PBS (Sigma-Aldrich, St. Louis, MO, USA). The animals were monitored daily. Body weight, stool consistency, presence of fecal blood, and survival rate were recorded to establish the clinical disease activity index (DAI). All mice were sacrificed at day 10 .

The entire colons of mice were removed to measure their lengths. For histopathological analysis, colonic segments were fixed in formalin solution, embedded in paraffin wax, and then sliced into $4-\mu \mathrm{m}$-thick sections before staining with hematoxylin and eosin. The histological score was calculated as previously described [9].

\section{Cytokine measurements}

A Potter-Elvehjem glass homogenizer was used to obtain colon homogenates. Samples from different groups were then centrifuged at $3 \times 10^{4} \mathrm{~g}$ for $10 \mathrm{~min}$ at $4^{\circ} \mathrm{C}$. A Cytometric Bead Array System (BD PharMingen, San Diego, CA, USA) was used to measure the cytokine level in the homogenates. The TGF- $\beta$ level in mouse serum was measured with a commercial ELISA kit (Invitrogen) according to the manufacturer's instructions.

\section{T cells apoptosis analysis}

Whole peripheral blood was treated with erythrocyte lysing solution. T cells were identified with a $\mathrm{CD}^{+}$antibody (BD PharMingen, San Diego, CA, USA), and Annexin-V Apoptosis Detection Kit I (BD PharMingen, San Diego, CA, USA) was applied to detect apoptotic cells in the $\mathrm{CD}^{+} \mathrm{T}$ cell population as described previously [1].

\section{Statistical analysis}

All data are presented as the mean \pm SD. Student's $t$-test was applied for comparisons between two groups, and one-way analysis of variance (ANOVA) was used for comparisons among multiple groups ( $>2) . P<0.05$ was considered significant.

\section{Results}

\section{Preparation of MSCs and Tregs in vitro}

Bone marrow cells were first collected and expanded in culture. At passage 3, all the cells exhibited a homogeneous fibroblast-like spindle shape with plastic-adherent properties. To characterize the culture- expanded MSCs, surface proteins of MSCs were examined with flow cytometry. The results showed that our MSCs were positive for CD73, CD90,CD105, and Sca-1 but lacking in the expression of CD45, CD34, CD14, or CD11b (Fig. 1D). These newly generated MSCs were also tested for their osteogenic or adipogenic differentiation capacity. After 3 weeks in osteogenic differentiation medium, Alizarin Red S staining showed that MSCs formed many mineralized nodules (Figs. 1A-1C). At the same time, numerous intracellular lipid droplets were observed by Oil Red O staining in adipogenic differentiation culture.

Tregs were prepared according to the literature. Flow cytometry data showed that these cells were expressing several Tregs-specific markers, GITR (glucocorticoidinduced tumor necrosis factor receptor-related protein), CTLA-4 (cytotoxic T-lymphocyte antigen-4), lymphoid homing receptor CD44, and more importantly FoxP3 at the same time (Fig. 1E). Based on these data, we concluded that we successfully generated MSCs and Tregs for further experiments.

Combined cell therapy with MSCs and Tregs could improve the clinical outcome in a murine colitis model

After being given 3\% DDS for 10 consecutive days, the C57BL/6 mice developed the typical syndrome of colon colitis with significant body weight loss, bloody diarrhea, mucosal ulceration, and shortening of the total colon length. The DAI, which was used to describe the severity of rectal bleeding, diarrhea, and weight loss, elevated to $7.8 \pm 0.83$ in the colitis group compared with the DAI of 1 in the normal C57/BL6 mice. In order to examine the effectiveness of different cell-based treatments, we separated the animals into four different groups. The experimental animals were given PBS (colitis group), MSCs, Tregs, or combined MSCs and Tregs at the 3rd day after DDS application. At day 10, the DAIs of the animals treated with MSCs or Tregs alone was reduced to $4.6 \pm 0.89$ or $4.6 \pm 0.55$, respectively. For the combined cell therapy, the DAI was significantly reduced to $3.2 \pm 0.45$ (Fig. 2A). Notably, the colitis animals exhibited severe weight loss and high a mortality rate dur- 

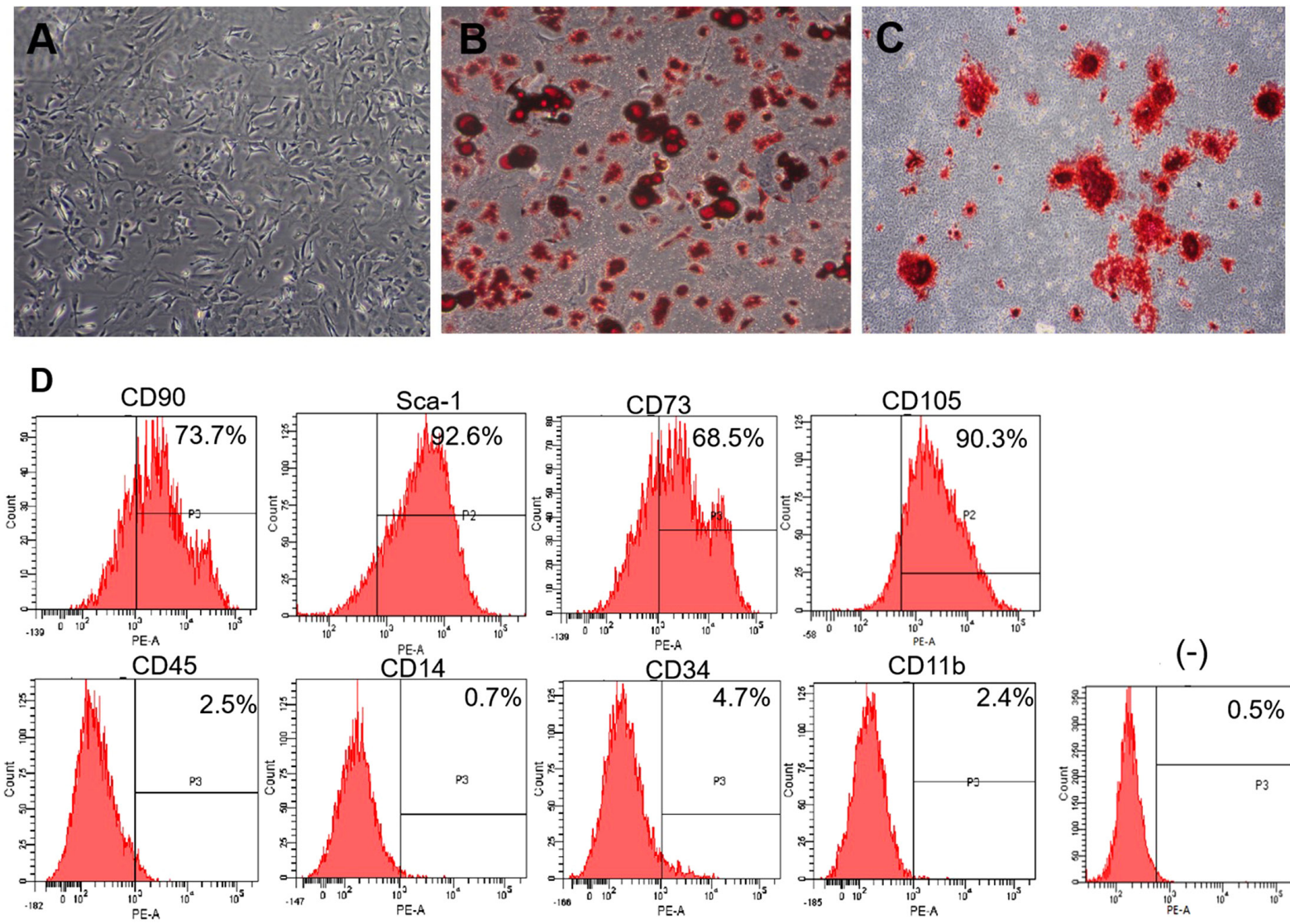

$(-)$

E
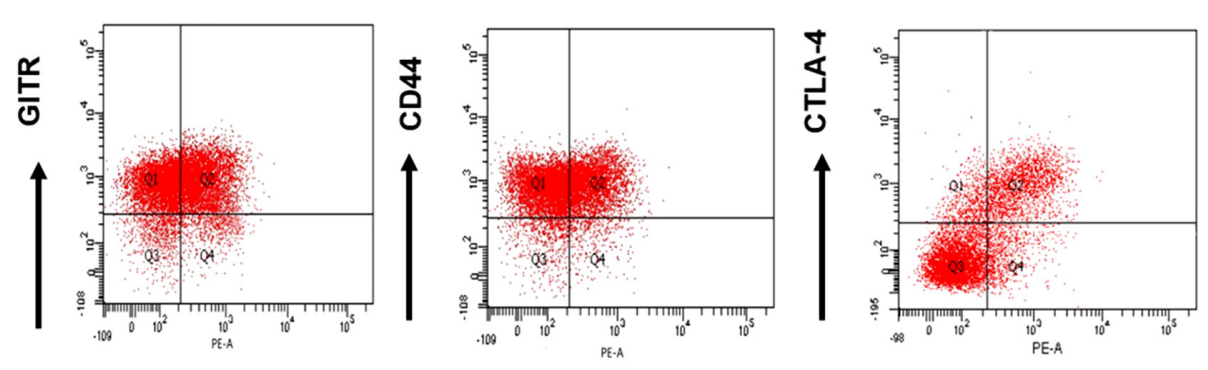

$(-)$

\section{Foxp3}

Fig. 1. Characterization of MSCs and Tregs. (A) MSCs in culture medium exhibited a spindle shape and plastic-adherent properties. (B) Adipogenic differentiation of MSCs was determined by Oil Red O staining. (C) Osteogenic differentiation of MSCs was determined by Alizarin Red S staining. (D) The surface antigens of MSCs were detected by flow cytometry. (E) The surface antigens of Tregs were detected by flow cytometry.

ing the experiment. The combined cell therapy was able to significantly maintain the body weight and survival rate in mice compared with therapy with either MSCs or Tregs alone (Figs. 2D and 2E).

The length of the colon was also measured in all the mice. DDS led to severe reduction of colon length (5.13 $\pm 0.42 \mathrm{~cm}$ ) in the colitis group compared with normal
C57/BL6 mice $(9.70 \pm 0.26 \mathrm{~cm})$. Therapy with either MSCs or Tregs was able to preserve the length of the colon $(8.1 \pm 0.36 \mathrm{~cm}$ for the MSC group and $8.1 \pm 0.15$ $\mathrm{cm}$ for the Tregs group). As we expected, the combined cell therapy demonstrated the most significant result in maintaining colon length $(9.03 \pm 0.15 \mathrm{~cm})$ (Figs. 2B and 2C). 

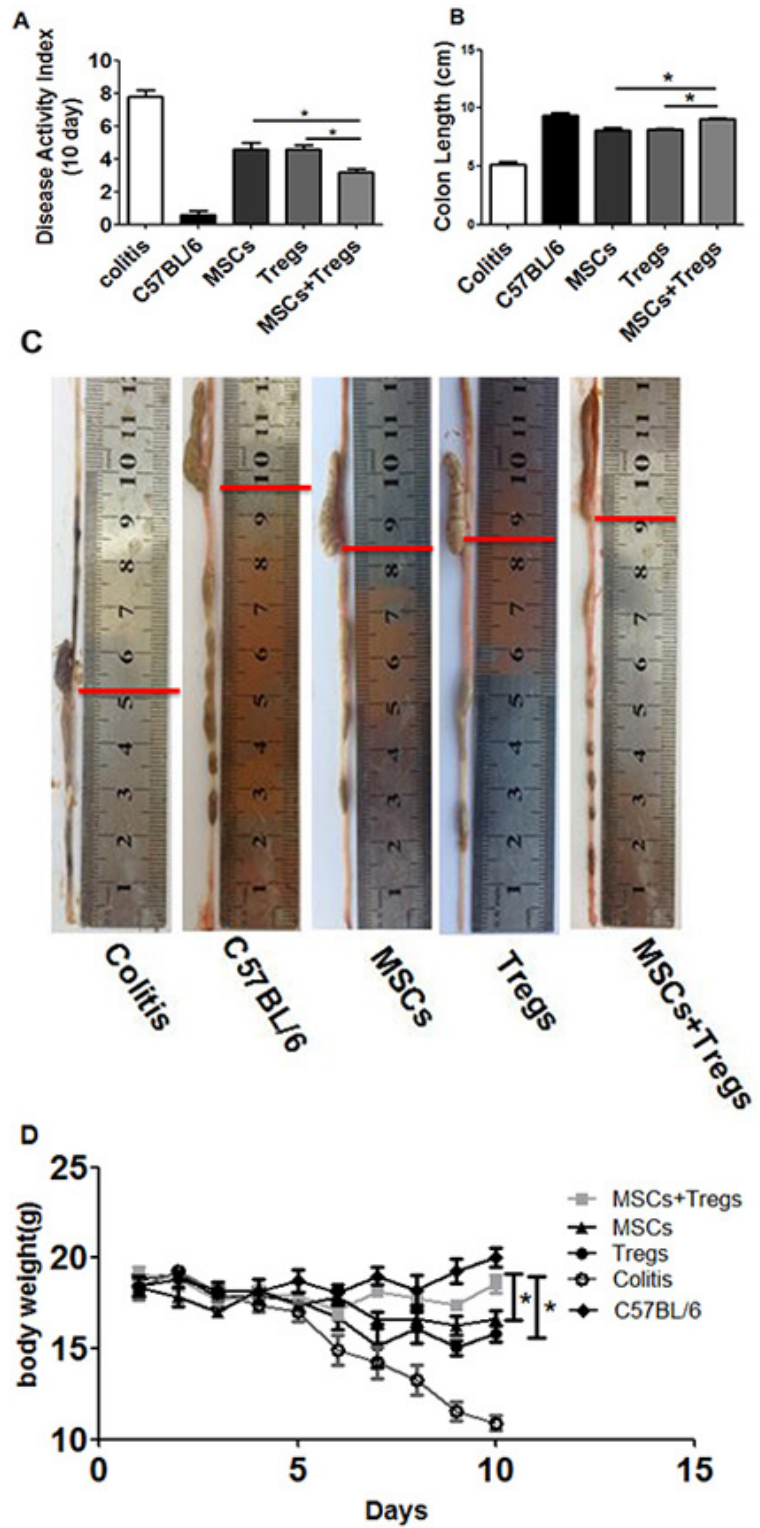

E

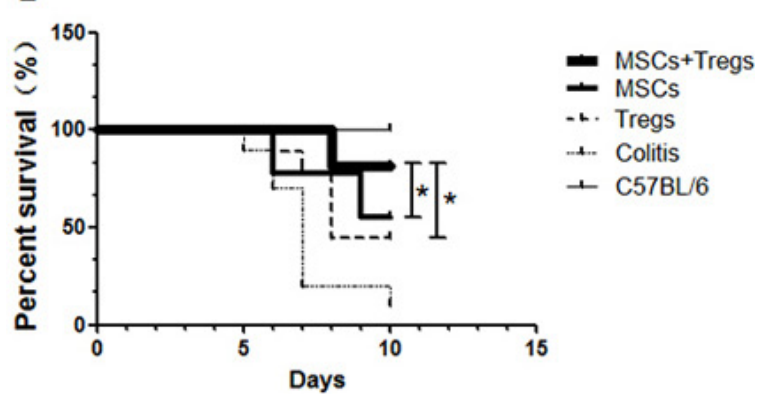

Fig. 2. The combined cell therapy ameliorated the symptoms of mice with colitis. The DAI of each group was evaluated at day 10. (B, C) The colon length of each group was measured at day 10. (D) Body weight during the experimental period. (E) Animal survival rate the experimental period. Results are presented as the mean \pm $\mathrm{SD}(\mathrm{n}=6) .{ }^{*} P<0.05$.
Combined cell therapy improved histological conditions of the colon with colitis

Previous studies have reported that DDS treatment could induce histological changes in the colon with colitis colon [1]. In this study, we also observed these changes, which mainly occurred in the distal part of the colon. Treatment with combined cells significantly reduced the extent of the inflammatory area and attenuated inflammatory cell infiltration. The histological activity indexs (HAIs) of the groups treated with only one type of cells reduced to $4.0 \pm 0.7$ (treated with MSCs) and $4.4 \pm 0.55$ (treated with Tregs) compared with the HAI of $5.6 \pm 1.44$ in the colitis group (treated with PBS). With combined cell therapy, the HAI score significantly decreased to $2.4 \pm 0.89$, which was very close to the score of the control C57/BL6 mice (HAI=1.0). The histological score data suggested that coadministration of MSCs and Tregs was very efficacious in preserving the colon morphology compared with single cell therapy (Fig. 3).

Coadministration of MSCs and Tregs suppressed the inflammatory cytokine levels in the colon with colitis

TNF- $\alpha$, IL-10, IFN- $\gamma$, IL-17A, and IL- $1 \beta$ are important pro-inflammatory cytokines, which have been suggested to play the major role during colitis development. In order to study the influence of different cell therapies on the presence of these cytokines, we examined their concentrations in colon homogenates. At day 10, the control C57/BL6 group had $0.76 \pm 0.20 \mathrm{ng} / \mathrm{g}$ TNF- $\alpha, 0.19 \pm 0.03$ $\mathrm{ng} / \mathrm{g}$ IL- $1 \beta, 0.58 \pm 0.23 \mathrm{ng} / \mathrm{g}$ IFN- $\gamma, 0.8 \pm 0.24 \mathrm{ng} / \mathrm{g}$ IL$17 \mathrm{~A}$, and $0.36 \pm 0.08 \mathrm{ng} / \mathrm{g}$ IL-10 in colon homogenates. In the mice of colitis, the levels of TNF- $\alpha$, IL- $1 \beta$, IFN- $\gamma$, IL-17A, and IL-10 were remarkably elevated to $6.1 \pm$ $0.88 \mathrm{ng} / \mathrm{g}, 4.96 \pm 0.73 \mathrm{ng} / \mathrm{g}, 5.18 \pm 0.70 \mathrm{ng} / \mathrm{g}, 6.92 \pm 0.64$ $\mathrm{ng} / \mathrm{g}$, and $4.42 \pm 0.94 \mathrm{ng} / \mathrm{g}$, respectively. Therapy with MSCs alone resulted in the TNF- $\alpha$, IL- $1 \beta$, IFN- $\gamma$, IL$17 \mathrm{~A}$, and IL-10 levels dropping to $2.80 \pm 0.74 \mathrm{ng} / \mathrm{g}, 2.11$ $\pm 0.43 \mathrm{ng} / \mathrm{g}, 3.36 \pm 0.70 \mathrm{ng} / \mathrm{g}, 2.8 \pm 0.74 \mathrm{ng} / \mathrm{g}$, and 2.5 $\pm 0.47 \mathrm{ng} / \mathrm{g}$, respectively, whereas, treatment with Tregs alone resulted in them dropping to $2.4 \pm 0.48 \mathrm{ng} / \mathrm{g}, 2.59$ $\pm 0.78 \mathrm{ng} / \mathrm{g}, 3.64 \pm 0.37 \mathrm{ng} / \mathrm{g}, 2.6 \pm 0.8 \mathrm{ng} / \mathrm{g}$, and 3.12 $\pm 0.57 \mathrm{ng} / \mathrm{g}$, respectively. When we combined both MSCs and Tregs in treatment, the cytokines were significantly decreased to $1.08 \pm 0.16 \mathrm{ng} / \mathrm{g}$ (TNF- $\alpha$ ), $0.38 \pm 0.07 \mathrm{ng} / \mathrm{g}$ (IL-1 $\beta$ ), $2.06 \pm 0.18 \mathrm{ng} / \mathrm{g}$ (IFN- $\gamma$ ), $1.24 \pm 0.42 \mathrm{ng} / \mathrm{g}$ (IL$17 \mathrm{~A}$ ), and $1.28 \pm 0.72 \mathrm{ng} / \mathrm{g}$ (IL-10), respectively (Fig. 4A). These data suggested that the combined therapy 

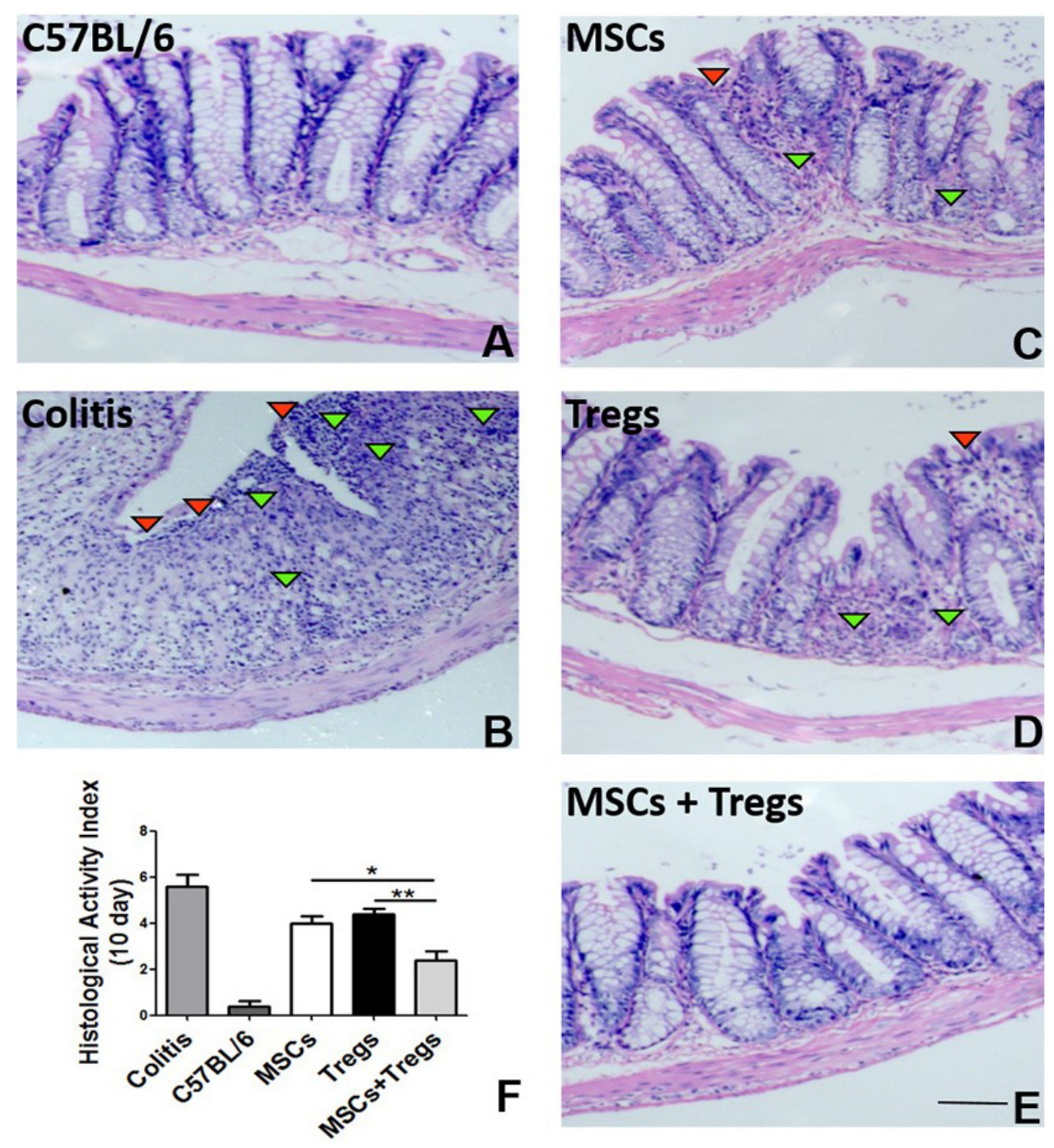

Fig. 3. Combined cell therapy improved histological conditions of mice with colitis. (A-E) Hematoxylin and eosin staining was performed to illustrate the colon morphology of each group. (F) The histological activity index chart of each group. Results are presented as the mean $\pm \mathrm{SD}(\mathrm{n}=6) . * P<0.05 ; * * P<0.01$. Scale bar $=200 \mu \mathrm{m}$.

with MSCs and Tregs together could significantly prevent inflammation in DDS-treated mouse colon and that this therapeutic effect might act through suppression of TNF- $\alpha$, IL-1 $\beta$, IL-10, IL-17A, and IFN- $\gamma$ levels.

\section{Cotransfer of MSCs and Tregs promoted $\mathrm{CD}^{+}{ }^{+} \mathrm{T}$ cell apoptosis}

It has been suggested that $\mathrm{CD}^{+} \mathrm{T}$ cell apoptosis is one of the critical mechanisms in MSC-based cell therapy in colitis treatment. We next investigated whether exogenous Tregs could improve the MSC function in promoting $\mathrm{T}$ cell apoptosis. We systematically transferred PBS, MSCs, Tregs, or combined MSCs and Tregs to mice with colitis. Peripheral blood samples were then collected at $6 \mathrm{~h}$ after cell transfer. Flow cytometry results showed that mice with colitis (treated with PBS) had a relatively low cell apoptosis rate with respect to their $\mathrm{CD}^{+} \mathrm{T}$ cell population $(6.86 \pm 0.13 \%)$. When treated with MSCs or Tregs, the ratio of apoptotic $\mathrm{CD}^{+} \mathrm{T}$ cells increased to $21.4 \pm 1.59 \%$ or $20 \pm 1.6 \%$ respectively. Combined cell therapy was able to significantly elevate the $\mathrm{CD}^{+} \mathrm{T}$ cell apoptotic rate to $26.1 \pm 0.81 \%$ (Figs. 5A and $5 \mathrm{~B})$. It was reported that apoptotic $\mathrm{T}$ cells could trigger TGF- $\beta$ production [22]. We next examined the level of TGF- $\beta$ in mouse serum after cell transfer. We found that the serum TGF- $\beta$ level in the mice with colitis was $9.33 \pm 2.49 \mathrm{ng} / \mathrm{ml}$. Transfer with either MSCs alone resulted in the serum TGF- $\beta$ level being elevated 

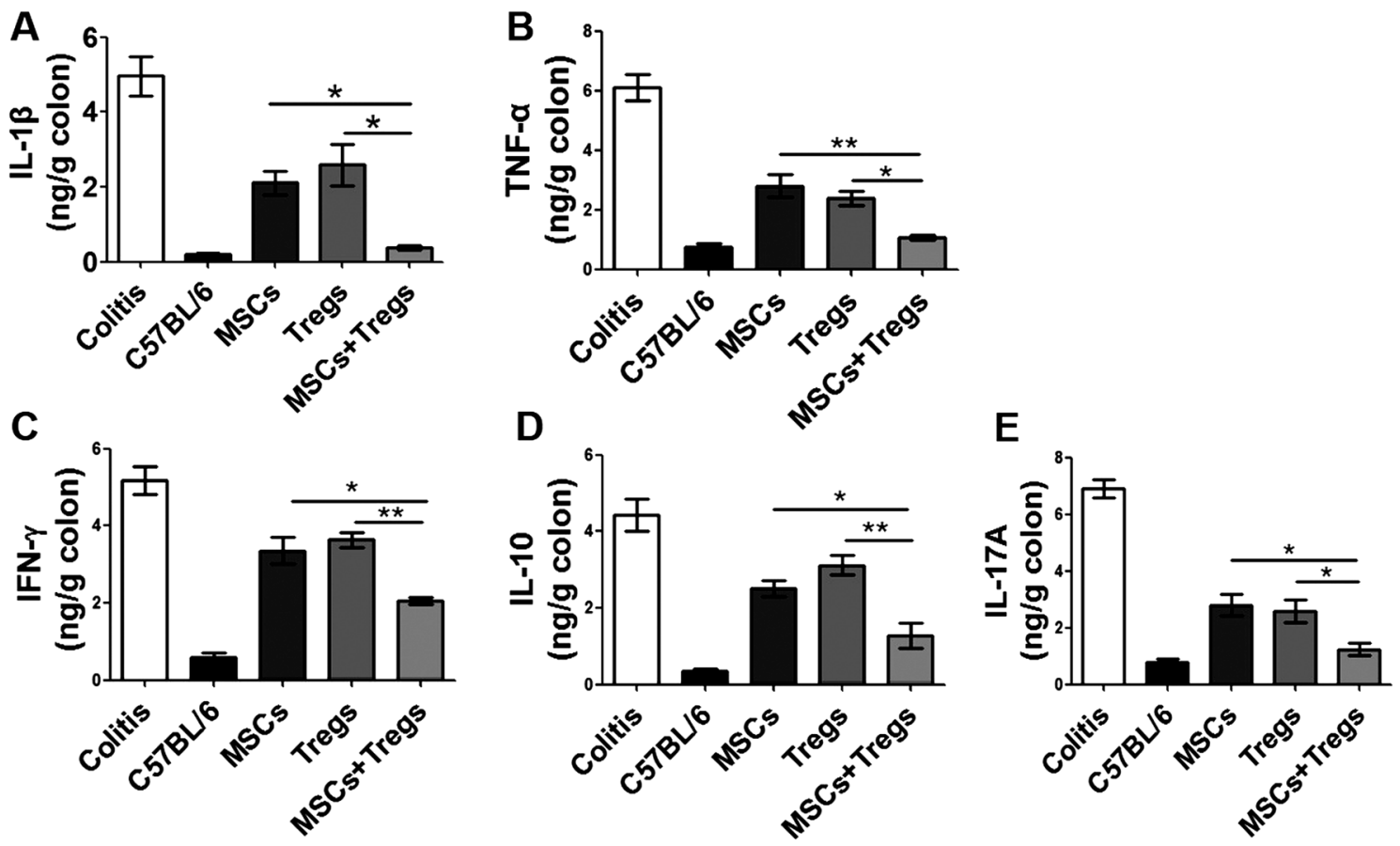

Fig. 4. Combined cell therapy suppressed the expression of inflammatory cytokines in the colitis model. (A-E) IL-1 $\beta$, TNF- $\alpha$, IFN-, IL-10, and IL-17A levels in colonic protein extracts were measured in each group. Results are presented as the mean $\pm \mathrm{SD}(\mathrm{n}=6)$. Mean \pm S.D. $\mathrm{n}=6 . * P<0.05 ; * * P<0.01$.
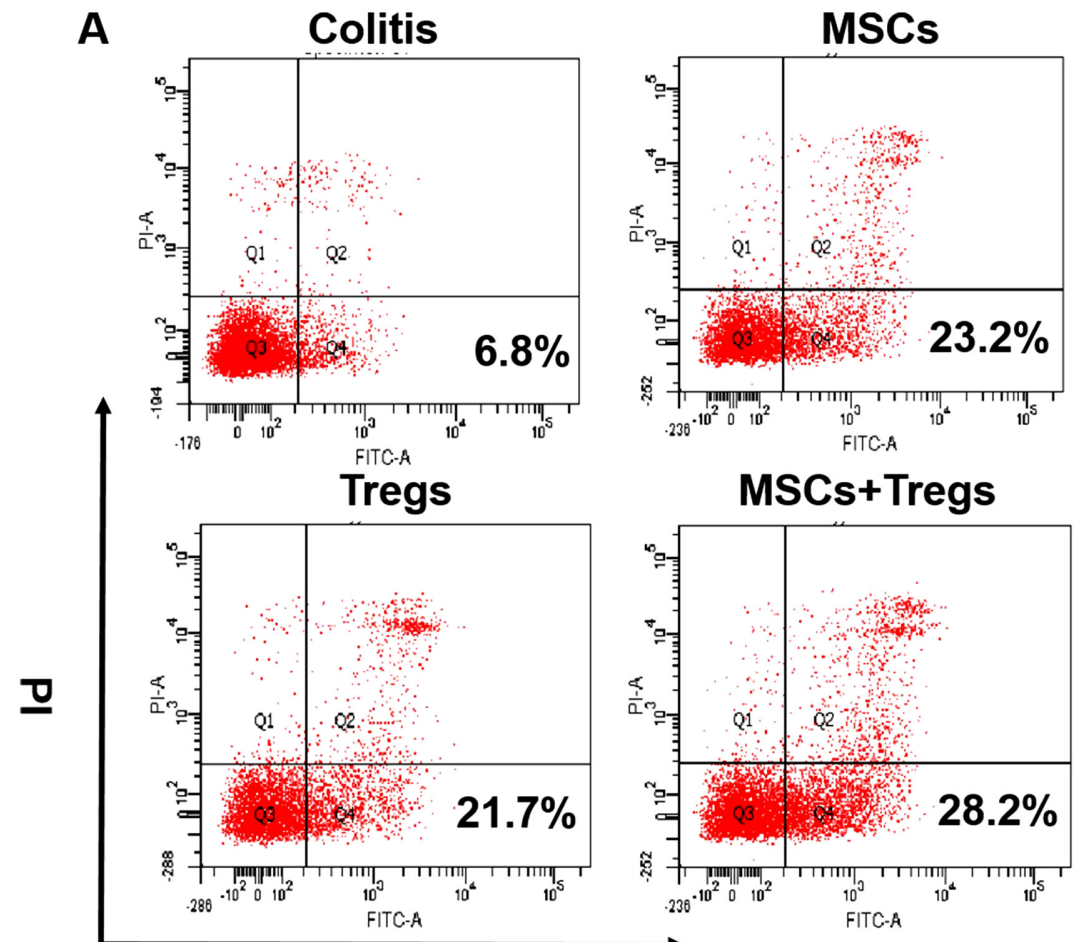

B
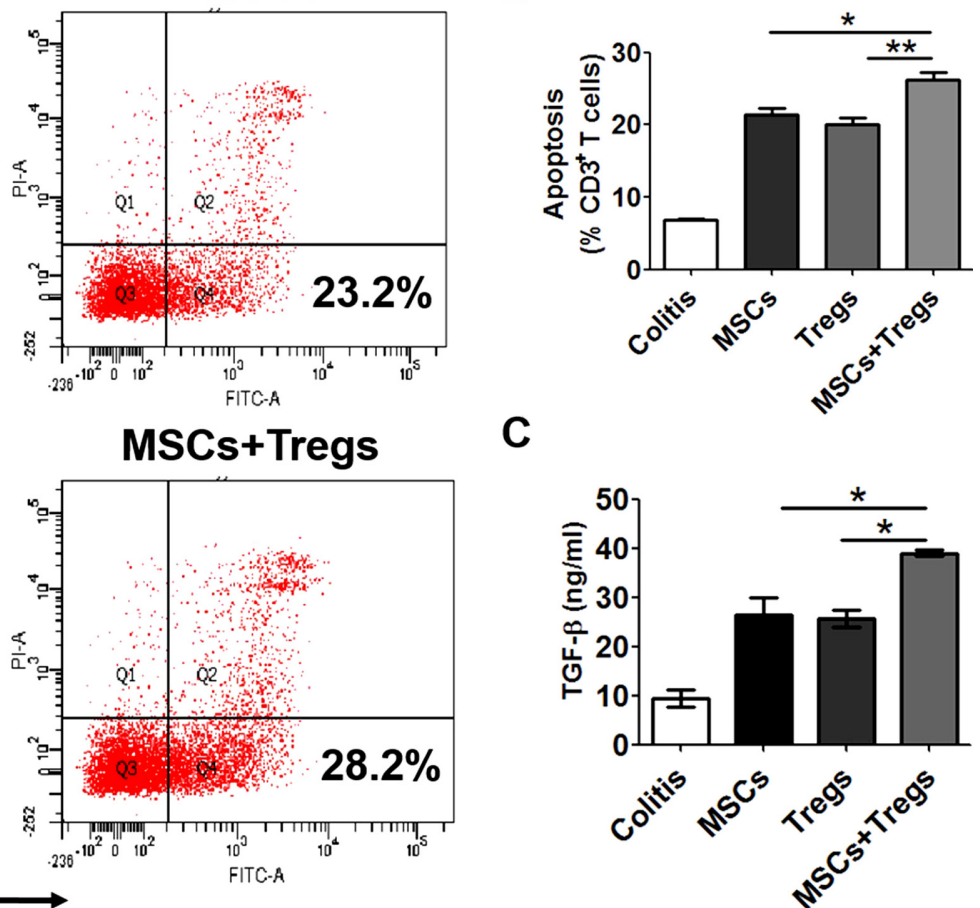

C

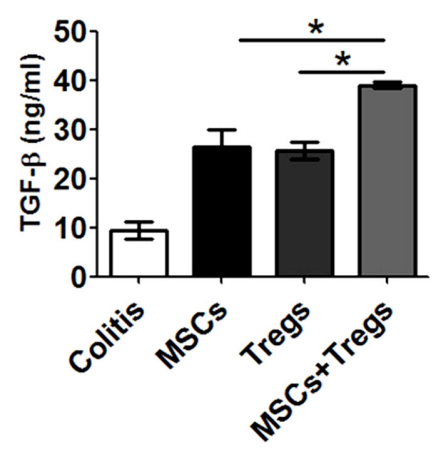

\section{Annexin V}

Fig. 5. The combined cell therapy promoted apoptosis in the $\mathrm{CD} 3^{+} \mathrm{T}$ cell population. (A, B) The apoptotic CD $3^{+} \mathrm{T}$ cells were quantified by flow cytometry. (C) Serum TGF- $\beta$ was measured in each group. Results are presented as the mean $\pm \mathrm{SD}(\mathrm{n}=6)$. ${ }^{*} P<0.05 ; * * P<0.01$. 
to $26.33 \pm 4.92 \mathrm{ng} / \mathrm{ml}$, whereas transfer with Tregs alone resulted in it being elevated to $24.66 \pm 3.68 \mathrm{ng} / \mathrm{ml} \mathrm{re-}$ spectively. When we combined both MSCs and Tregs in treatment, the serum TGF- $\beta$ significantly increased to $39.03 \pm 0.85 \mathrm{ng} / \mathrm{ml}$ (Fig. 5C). These data suggested that combining Tregs with MSCs in treatment could enhance $\mathrm{CD}^{+} \mathrm{T}$ cell apoptosis.

\section{Discussion}

Use of MSCs to treat IBD, and GVHD, and other immune diseases has been widely attempted. Although some progress has been made, the therapeutic effectiveness of MSCs still needs to be improved. Moreover, Tregs have gained attention, as they can facilitate the function of MSCs in many aspects. Multiple studies have suggested that MSCs are capable of inducing Tregs from a population of T cells in vivo and in vitro. However, the number of endogenous Tregs induced by MSCs was limited. In the present report, we demonstrated that exogenous Tregs played an important role in boosting the immune regulation function of MSCs. We applied combined cell therapy with both MSCs and Tregs to a DSSinduced colits mouse model and demonstrated that Tregs could enhance the curative effects of MSCs in several aspects. Our results suggested a novel strategy for IBD treatment.

Although the detailed mechanism of IBD still remains under defined, accumulating evidence indicates that the inflammatory factors play an important role in colitis pathogenesis. Previous studies demonstrated that MSCs could regulate the expression of many inflammatory cytokines, suppress inflammatory cell infiltration and proliferation, and promote $\mathrm{T}$ cells apoptosis. The immune regulation function of MSCs was thought to be the result of secretion of soluble factors and cell-to-cell contacts. MSCs secrete certain cytokines and chemokines, which could induce Tregs differentiation. Then, these newly generated Tregs facilitate the immune tolerance of MSCs, thus enhancing the MSC's immune regulation fuction of the MSCs $[14,18,25]$. However, even with the presence of endogenous Tregs, the outcome of MSC transfer alone is not comparable with the combined cell therapy in treating DDS-induced colitis. This may be due to a time gap between MSCs injection of MSCs and induction of Tregs induction or simply there not being enough endogenous Tregs in the system [16, 17]. However, like some previous studies $[1,8-10]$, we did not measure the frequency of Tregs or size of the Treg population in colonic lamina propria before and after MSC transfer. This is an important point that which should be explored in the further studies. Recent studies showed that the addition of Tregs may improve the condition of established GVHD. Interestingly, several studies have suggested that administration with Tregs could only suppress autoimmunity and prevent overexuberant immune responses when treating autoimmune diseases $[7,19]$. We also noticed that administering Tregs alone could ease the DDS-induced IBD in our study. Butin the case of inflammatory environments, Tregs may convert to Th17 cells and lose their immune suppressive capability $[15,23,28]$. This would certainly weaken the effectiveness of Tregs only treatment. As a result, the key to improving the effectiveness of colitis treatment might be administration of both active MSCs and Tregs at the same time.

In our study, we first prepared Tregs in vitro. This exogenous Tregs population could resist to inflammatory cytokines and maintain immune suppressive function [12]. Then, we combined MSCs and Tregs and infused them into a DSS-induced colitis mouse model. Body weight was significantly improved compared with the data from groups treated with either MSCs or Tregs alone. In the inflamed area, the histological appearance of the colon was ameliorated remarkably. The severity of clinical symptoms dramatically decreased following the combined cell therapy. The mechanism of colitis is still under defined. However, many studies have shown that an excess of TNF- $\alpha$, IL-10, IFN- $\gamma$, IL-17A, and IL$1 \beta$ may play a significant role in the pathogenesis of colitis [13]. We examined these cytokines in our study. The data from ELISA assays showed that the levels of TNF- $\alpha$, IL-10, IFN- $\gamma$, IL-17A, and IL- $1 \beta$ noticeably deceased in serum and surrounding tissue after the combined cell therapy. In the colitis mice, IL-10, an important anti-inflammatory cytokine, was compensatory upregulated as expected. However, IL-10 together with four other important cytokines were downregulated after cell transfer. These results suggested that MSCs and/or Tregs had significant anti-inflammatory effects as previously reported $[2,10]$. And that these effects probably were not mediated by the presence of IL-10 or other cytokines studied in this report. IL-10 could upregulate the JAK-STAT3 signaling pathway through inhibition of the NF- $\mathrm{KB}$ signal $[21,23,24]$. Thus, the anti-inflammatory effects of cell transfer in this study might not be 
through these two signaling pathways, which is consistent with a finding of Akiyama et al. [1]. Further studies need to be performed to explore the detailed mechanism of the anti-inflammatory effects from MSCs and/or Tregs. We also investigated the apoptotic $\mathrm{CD}^{+} \mathrm{T}$ cells in our system. As a result, we found a sharp increase in the ratio of apoptotic $\mathrm{CD}^{+} \mathrm{T}$ cells when transfer Tregs together with MSCs. Although we did not analyze the situation of apoptotic cytokine-producing T cells, such as IFN- $\gamma$ - and IL-17-producing T cells, both cytokines decreased in the colon after cell transfer, which may suggest that the IFN- $\gamma$-and IL-17-producing colon T cells also undergo apoptosis. Interestingly, serum TGF- $\beta$ significantly increased after cell transfer. The increased TGF- $\beta$ would then contribute to the therapeutic effects by regulating the Tregs immune tolerance of Tregs.

In conclusion, the therapy with combined MSCs and Tregs remarkably decreased the clinical characteristics and pathological manifestations in the colitis mouse model. These data suggest a potential approach in preventing human IBDs.

\section{Conflict of Interest}

The authors declare that they have no competing financial interests.

\section{Acknowledgment}

This work was supported by the National Natural Science Foundation of China (31371473, 31571508 to D.Y. and 31571510 to T.Z.), Key research project of Chongqing Health and Family Planning Commision (2011-1062 to D.Y.), the key project of Chongqing Yuzhong Science and Technology Commission (2012 to D.Y.), the Science and technology project of Chongqing Yubei Science and Technology Commission ([2011]33 to D.Y.) and Chongqing Science and Technology Commission (cstc2014jcyjA10045 to T.Z.).

\section{References}

1. Akiyama, K., Chen, C., Wang, D., Xu, X., Qu, C., Yamaza, T., Cai, T., Chen, W., Sun, L., and Shi, S. 2012. Mesenchymal-stem-cell-induced immunoregulation involves FASligand-/FAS-mediated T cell apoptosis. Cell Stem Cell 10: 544-555. [Medline] [CrossRef]

2. Salas, A., Ricart, E., and Panés, J. 2009. Cell therapies for inflammatory bowel diseases. Expert Rev. Gastroenterol.
Hepatol. 3: 321-324. [Medline] [CrossRef]

3. Augello, A., Tasso, R., Negrini, S.M., Cancedda, R., and Pennesi, G. 2007. Cell therapy using allogeneic bone marrow mesenchymal stem cells prevents tissue damage in collagen-induced arthritis. Arthritis Rheum. 56: 1175-1186. [Medline] [CrossRef]

4. Bouma, G. and Strober, W. 2003. The immunological and genetic basis of inflammatory bowel disease. Nat. Rev. Immunol. 3: 521-533. [Medline] [CrossRef]

5. Beyth, S., Borovsky, Z., Mevorach, D., Liebergall, M., Gazit, Z., Aslan, H., Galun, E., and Rachmilewitz, J. 2005. Human mesenchymal stem cells alter antigen-presenting cell maturation and induce T-cell unresponsiveness. Blood 105: 2214-2219. [Medline] [CrossRef]

6. Chamberlain, G., Fox, J., Ashton, B., and Middleton, J. 2007. Concise review: mesenchymal stem cells: their phenotype, differentiation capacity, immunological features, and potential for homing. Stem Cells 25: 2739-2749. [Medline] [CrossRef]

7. Dousdampanis, P., Trigka, K., and Mouzaki, A. 2016. Tregs and kidney: From diabetic nephropathy to renal transplantation. World J. Transplant. 6: 556-563. [Medline] [CrossRef]

8. Duijvestein, M., Wildenberg, M.E., Welling, M.M., Hennink, S., Molendijk, I., van Zuylen, V.L., Bosse, T., Vos, A.C., de Jonge-Muller, E.S., Roelofs, H., van der Weerd, L., Verspaget, H.W., Fibbe, W.E., te Velde, A.A., van den Brink, G.R., and Hommes, D.W. 2011. Pretreatment with interferon- $\gamma$ enhances the therapeutic activity of mesenchymal stromal cells in animal models of colitis. Stem Cells 29: 1549-1558. [Medline] [CrossRef]

9. Fan, H., Zhao, G., Liu, L., Liu, F., Gong, W., Liu, X., Yang, L., Wang, J., and Hou, Y. 2012. Pre-treatment with IL-1 $\beta$ enhances the efficacy of MSC transplantation in DSS-induced colitis. Cell. Mol. Immunol. 9: 473-481. [Medline] [CrossRef]

10. González, M.A., Gonzalez-Rey, E., Rico, L., Büscher, D., and Delgado, M. 2009. Adipose-derived mesenchymal stem cells alleviate experimental colitis by inhibiting inflammatory and autoimmune responses. Gastroenterology 136: 978-989. [Medline] [CrossRef]

11. Glennie, S., Soeiro, I., Dyson, P.J., Lam, E.W., and Dazzi, F. 2005. Bone marrow mesenchymal stem cells induce division arrest anergy of activated T cells. Blood 105: 2821-2827. [Medline] [CrossRef]

12. Horwitz, D.A., Zheng, S.G., and Gray, J.D. 2008. Natural and TGF- $\beta$-induced Foxp3(+)CD4(+) CD25(+) regulatory T cells are not mirror images of each other. Trends Immunol. 29: 429-435. [Medline] [CrossRef]

13. He, X.W., He, X.S., Lian, L., Wu, X.J., and Lan, P. 2012. Systemic infusion of bone marrow-derived mesenchymal stem cells for treatment of experimental colitis in mice. Dig. Dis. Sci. 57: 3136-3144. [Medline] [CrossRef]

14. Jiang, X.X., Zhang, Y., Liu, B., Zhang, S.X., Wu, Y., Yu, X.D., and Mao, N. 2005. Human mesenchymal stem cells inhibit differentiation and function of monocyte-derived dendritic cells. Blood 105: 4120-4126. [Medline] [CrossRef]

15. Komatsu, N., Mariotti-Ferrandiz, M.E., Wang, Y., Malissen, B., Waldmann, H., and Hori, S. 2009. Heterogeneity of natu- 
ral Foxp3+ T cells: a committed regulatory T-cell lineage and an uncommitted minor population retaining plasticity. Proc. Natl. Acad. Sci. USA 106: 1903-1908. [Medline] [CrossRef]

16. Le Blanc, K., Rasmusson, I., Sundberg, B., Götherström, C., Hassan, M., Uzunel, M., and Ringdén, O. 2004. Treatment of severe acute graft-versus-host disease with third party haploidentical mesenchymal stem cells. Lancet 363: 14391441. [Medline] [CrossRef]

17. Lim, J.Y., Park, M.J., Im, K.I., Kim, N., Jeon, E.J., Kim, E.J., Cho, M.L., and Cho, S.G. 2014. Combination cell therapy using mesenchymal stem cells and regulatory T-cells provides a synergistic immunomodulatory effect associated with reciprocal regulation of TH1/TH2 and th17/treg cells in a murine acute graft-versus-host disease model. Cell Transplant. 23: 703-714. [Medline] [CrossRef]

18. Lee, E.S., Lim, J.Y., Im, K.I., Kim, N., Nam, Y.S., Jeon, Y.W., and Cho, S.G. 2015. Adoptive transfer of treg cells combined with mesenchymal stem cells facilitates repopulation of endogenous treg cells in a murine acute GVHD model. PLOS ONE 10: e138846. [Medline] [CrossRef]

19. McDonald-Hyman, C., Flynn, R., Panoskaltsis-Mortari, A., Peterson, N., MacDonald, K.P., Hill, G.R., Luznik, L., Serody, J.S., Murphy, W.J., Maillard, I., Munn, D.H., Turka, L.A., Koreth, J., Cutler, C.S., Soiffer, R.J., Antin, J.H., Ritz, J., and Blazar, B.R. 2016. Therapeutic regulatory T-cell adoptive transfer ameliorates established murine chronic GVHD in a CXCR5-dependent manner. Blood 128: 1013-1017. [Medline] [CrossRef]

20. Nauta, A.J. and Fibbe, W.E. 2007. Immunomodulatory properties of mesenchymal stromal cells. Blood 110: 3499-3506. [Medline] [CrossRef]

21. Pattison, M.J., Mackenzie, K.F., and Arthur, J.S. 2012. Inhibition of JAKs in macrophages increases lipopolysaccharide-induced cytokine production by blocking IL-10-mediated feedback. J. Immunol. 189: 2784-2792. [Medline] [CrossRef]

22. Perruche, S., Zhang, P., Liu, Y., Saas, P., Bluestone, J.A., and
Chen, W. 2008. CD3-specific antibody-induced immune tolerance involves transforming growth factor- $\beta$ from phagocytes digesting apoptotic T cells. Nat. Med. 14: 528-535.

23. Rafei, M., Campeau, P.M., Aguilar-Mahecha, A., Buchanan, M., Williams, P., Birman, E., Yuan, S., Young, Y.K., Boivin, M.N., Forner, K., Basik, M., and Galipeau, J. 2009. Mesenchymal stromal cells ameliorate experimental autoimmune encephalomyelitis by inhibiting CD4 Th17 T cells in a CC chemokine ligand 2-dependent manner. J. Immunol. 182: 5994-6002. [Medline] [CrossRef]

24. Ren, Y.X., Yang, J., Sun, R.M., Zhang, L.J., Zhao, L.F., Li, B.Z., Li, L., Long, H.T., Sun, Q.M., Huang, Y.C., and Li, X.J. 2016. Viral IL-10 down-regulates the "MHC-I antigen processing operon" through the NF- $\kappa \mathrm{B}$ signaling pathway in nasopharyngeal carcinoma cells. Cytotechnology 68: 26252636. [Medline] [CrossRef]

25. Schliesser, U., Streitz, M., and Sawitzki, B. 2012. Tregs: application for solid-organ transplantation. Curr. Opin. Organ Transplant. 17: 34-41. [Medline] [CrossRef]

26. Yañez, R., Lamana, M.L., García-Castro, J., Colmenero, I., Ramírez, M., and Bueren, J.A. 2006. Adipose tissue-derived mesenchymal stem cells have in vivo immunosuppressive properties applicable for the control of the graft-versus-host disease. Stem Cells 24: 2582-2591. [Medline] [CrossRef]

27. Yang, X.O., Nurieva, R., Martinez, G.J., Kang, H.S., Chung, Y., Pappu, B.P., Shah, B., Chang, S.H., Schluns, K.S., Watowich, S.S., Feng, X.H., Jetten, A.M., and Dong, C. 2008. Molecular antagonism and plasticity of regulatory and inflammatory T cell programs. Immunity 29: 44-56. [Medline] [CrossRef]

28. Zappia, E., Casazza, S., Pedemonte, E., Benvenuto, F., Bonanni, I., Gerdoni, E., Giunti, D., Ceravolo, A., Cazzanti, F., Frassoni, F., Mancardi, G., and Uccelli, A. 2005. Mesenchymal stem cells ameliorate experimental autoimmune encephalomyelitis inducing T-cell anergy. Blood 106: 17551761. [Medline] [CrossRef] 